\title{
Partisipasi Masyarakat Dalam Penyelenggaraan Pemilukada Kabupaten Buton Tahu n 2012 (Studi Pada Kelurahan Jaya Bakti Kecamatan Sampolawa)
}

\author{
Jusri \\ Program Studi Ilmu Pemerintahan, Fakultas Ilmu Sosial dan Ilmu Politik \\ Universitas Muhammadiyah Buton, Jl. Betoambari No. 36 Baubau
}

\begin{abstract}
ABSTRAK
Tujuan penelitian ini adalah untuk mendeskripsikan bagaimana partisipasi masyarakat Kelurahan Jaya Bakti Kecamatan Sampolawa dalam penyelenggaraan Pemilukada Kabupaten Buton.

Metode penelitian yang digunakan adalah deskriptif. Data dikumpulkan melalui (1) Penelitian kepustakaan (2) Penelitian lapangan (3) wawancara dan (4) Dokumentasi. Data kemudian dianalisis secara interaktif dan disajikan secara deskriptif.

Hasil penelitian menunjukkan bahwa partisipasi masyarakat Kelurahan Jaya Bakti tergolong rendah. Yakni : (1) Kesadaran untuk mendaftarkan diri sebagai Pemilih Pada Pemilukada, (2) Partisipasi pada pelaksanaan Kampanye Calon Kepala Daerah adapun partisipasi hanya dilakukan oleh adanya motivasi sebagai huburan semata, dan (3) partisipasi pada saat pelaksanaan pemungutan suara. Beberapa factor yang menyebabkan rendahnya partisipasi seperti; minimnya pengetahuan politik masyarakat, minimnya sarana informasi tentang proses pemilukada dan jauhnya lokasi pemungutan suara.
\end{abstract}

Kata Kunci : Partisipasi Politik, Pemilukada, Buton 


\section{A. Pendahuluan}

Otonomi daerah membawa dampak yang luas terhadap berkembangnya demokrasi di Indonesia, serta membawa harapan besar untuk kesejahteraan rakyat dan kemakmuran daerah.Melalui pemilihan kepala daerah secara langsung masyarakat dapat menentukan pilihannya sendiri. Hal ini akan membawa perubahan pandangan masyarakat terhadap pemerintahan di daerah, karena calon yang akan memimpin dipilih langsung oleh rakyat. Proses ini membuktikan adanya sikap demokratis dan transparansi bagi rakyat yang akan memilih seorang pemimpin secara terbuka. Selain itu pemimpin yang terpilih nantinya akan memberikan kemampuan yang terbaik dalam mengelola dan mengatur kepemerintahannya. Harapan terbesar adalah pelayanan publik dan kesejahteraan akan lebih baik melalui Pemilukada langsung ini.

Berlakunya Undang-Undang Nomor 23 Tahun 2014 Tentang Pemerintahan Daerah merupakan momentum yang baik dalam proses penyelenggaraan demokrasi di Indonesia yang semakin terbuka dan akuntabel. Perubahan ini setidaknya membawa implikasi yang besar bagi kehidupan di daerah. Pemimpin di daerah akan mendapat legitimasi yang kuat melalui Pemilukada langsung. Dengan demikian masyarakat akan memiliki trust yang tinggi pada pemimpinnya untuk bersama-sama membangun daerahnya. Hal inilah yang menjadi modal dasar dalam pelaksanaan pembangunan di daerah yaitu sebagai modal sosial dan kohesivitas masyarakat lokal yang memiliki nilai stratetegis dalam pelaksanaan democratic governance di tingkat lokal.

Harapan besar pemerintah dengan adanya Undang - Undang Nomor 23 Tahun 2014 Tentang Pemerintahan Daerah adalah rakyat dapat mengetahui dan memahami isi yang terkandung dalam undang-undang tersebut, sehingga lebih dapat meningkatkan pengetahuan serta wawasan politik atau pendidikan politik yang lebih dewasa terutama lebih memperhatikan aspek-aspek hubungan antar susunan pemerintahan dan antar pemerintah daerah. Implikasi lebih lanjut melalui pemahaman undang-undang tersebut akan membuat rakyat menjadi paham politik, membangun tingkat kesadaran dalam berpolitik, serta masyarakat lebih kreatif dalam memilih calon kepala daerah yang mempunyai pemikiran yang ingin membangun daerahnya untuk maju dan sejahtera serta pelayanan publik yang lebih baik.

Dalam konteks penguatan demokratisasi, pemilukada langsung berpeluang untuk melakukan pematangan dan penyadaran berdemokrasi. Masyarakat yang memiliki kesadaran berdemokrasi merupakan langkah awal dalam menuju proses demokrasi yang benar dan substansial. Inilah kehidupan demokrasi yang sebenarnya, bukan demokrasi inprosedural yang selama ini telah dijalankan dalam kehidupan berdemokrasi. Jangan demokrasi dimaknai sebagai proses yang memiliki implikasi anggaran besar dan tidak bermanfaat, terjadinya konspirasi, pelanggaran dan keamanan yang tidak terjamin, etika politik yang terabaikan, saat inilah cara pandang demikian harus dirubah walaupun realitas ini terlihat dari proses demokrasi langsung yang justru menimbulkan berbagai persoalan yang kompleks. Tingkat konflik yang tinggi, konspirasi politik, money politic bahkan dampak lain adalah tingginya korupsi di daerah.

Terlepas dari permasalahan tersebut sebenarnya Pemilukada langsung memiliki makna strategis yaitu pendidikan politik sekaligus penguatan potensi lokal yang selama ini terabaikan.Pendidikan politik tersebut dapat efektif hanya melalui pendidikan kewarganegaraan (civic 
education).Aktualisasi dari civic education terletak kepada tingkat partipasi politik rakyat di setiap momentum politik seperti pemilu ataupun Pemilukada. Partisipasi politik yang lemah berakibat pada sebuah realitas politik yang kini menggejala di permukaan dan terkait dengan era otonomi daerah yaitu terjadinya kesenjangan politik antara masyarakat sipil dengan lembaga kekuasaan lokal, di mana aktor pelaksana kekuasaan lokal sering melakukan langkah pengambilan dan pelaksanaan kebijakan politik yang tidak selaras dengan aspirasi kolektif masyarakat sipil.

Buton adalah salah satu kabupaten di Indonesia yang telah melaksanakan Pemilukada secara langsung sejak tahun 2006, dan saat itu jugalah masyarakat mulai berpartisipasi langsung terhadap penentuan calon pemimpinnya untuk pertama kalinya. Masyarakat sebagai aktor utama dalam pemilihan ini dituntut agar lebih partisipatif dalam segala bentuk tahapan penyelenggaraan pemilukada.

Partisipasi yang diharapkan tentunya bukanlah hanya sekedar dilihat dari satu aspek saja tetapi harus dilihat dari semua aspek tahapan penyelenggaraan termasuk kesadaran masyarakat akan terjaganya keamanan dan stabilitas politik pada saat menjelang dan sesudah pelaksanaan Pemilukada tersebut.

Pemilihan Kepala Daerah Kabupaten Buton dilaksanakan dengan aman walaupun masih terjadi kelemahan-kelemahan pada tingkat penyelenggara pemilukada. Hal tersebut setidaknya berdampak pada tingkat partisipasi masyarakat terhadap proses pemilihan. Di Kelurahan Jaya Bakti kecamatan sampolawa, partisipasi masyarakat terhadap pemilihan kepala daerah cenderung menurun.Hal ini bisa dilihat dari peran serta masyarakat mulai dari pendaftaran pemilih, respon masyarakat terhadap daftar wajib pilih, tahapan kampanye dan pemungutan suara.Hal ini bisa disebabkan oleh berbagai faktor seperti rendahnya tingkat pendidikan masyarakat, jenuhnya masyarakat terhadap pemilihan langsung atau juga disebabkan karena kurangnya minat masyarakat terhadap figur-figur yang ada.Berdasarkan uraian tersebut, penulis tertarik untuk melakukan penelitian dengan judul : Partisipasi Masyarakat Dalam Penyelenggaraan Pemilukada di Kelurahan Jaya Bakti Kecamatan Sampolawa Kabupaten Buton.

\section{B. Metode Penelitian}

Jenis penelitian yang digunakan adalah penelitian deskriptif Kualitatif dengan Informan yang digunakan dalam penelitian ini berjumlah 8 orang. Untuk memperoleh data, informasi-informasi, keterangan dan fakta-fakta, penulis menggunakan teknik pengumpulan data Penelitian kepustakaan, Penelitian lapangan dan Wawancara. Teknik analisa data yang digunakan dalam penelitian ini adalah Reduksi data, Sajian data dan Penarikan kesimpulan.

\section{Hasil Penelitian Dan Pembahasan}

\section{a. Pendaftaran Wajib Pilih}

Dalam setiap PEMILU, baik itu pemilihan DPR, DPRD, DPD, Presiden dan pemilihan Kepala Daerah selalu melalui tahapan atau proses yang telah ditetapkan sebelumnya oleh pihak penyelenggara. Adapun tahapan awal dalam penyelenggaraan pemilu tersebut adalah pendaftaran wajib pilih.Biasanya, Panitia Pemungutan Suara menerima Daftar Pemilih Sementara dari Komisi Pemilihan Umum Kabupaten/Kota untuk kemudian divalidasi sebelum ditetapkan sebagai Daftar Pemilih tetap (DPT).

Sebelum ditetapkan sebagai Daftar Pemilih Tetap terlebih dahulu pihak penyelenggara (PPS) mengumumkan Daftar Pemilih Sementara (DPS) yang ditempel di 
papan pengumuman untuk meminta tanggapan masyarakat terhadap DPS tersebut. Hal inilah sebagai tahap awal masyarakat dimintai secara langsung untuk berpartisipasi dalam tahapan penyelenggaraan PEMILUKADA. Seharusnya seluruh masyarakat yang sudah memenuhi syarat untuk menjadi wajib pilih dapat memastikan namanya apakah sudah terdaftar dalam Daftar Pemilih Sementara tersebut. Bila tidak terdaftar, maka pada saat itu juga masyarakat dapat mendaftarkan dirinya untuk didata sebagai wajib pilih tambahan yang nantinya akan tercatat dalam daftar pemilih tertap.Peran serta masyarakat dalam tahapan ini sangatlah penting karena akan berdampak langsung terhadap penyelenggaraan PEMILUKADA.

Berdasarkan gambaran tersebut diatas maka sangat jelas bahwa tingkat partisipasi masyarakat dalam hal mengecek namanya dalam Daftar Pemilih Sementara yang terpampang di papan pengumuman masih sangat rendah.

Hasil wawancara dengan ketua PPS Kelurahan Jaya Bakti menyatakan bahwa presentase partisipasi masyarakat terhadap proses pendaftaran pemilihsementara sangatlah rendahbila dibandingkan dengan pemilu sebelumnya. Hal ini bisa dilihat dari respon/partisipasi masyarakat terhadap pengumuman Daftar Pemilih Sementara yang ditempel pada papan pengumuman. Kebanyakan partisipasisifatnya hanya berhubungan dengan kepentingankepentingan untuk para calon dalam artian bahwa para tim-tim sukses yang langsung mengecek nama-nama wajib pilih pada Panitia Pemungutan Suara yang mereka anggap bahwa nama-nama yang mereka cek tersebut adalah para pendukungnya.

Rendahnya partisipasi masyarakat tersebut disebabkan oleh beberapa faktor antara lain :
1)
Kurangnya
sosialisasi
atau
penyebarluasan informasi oleh pihak

penyelenggara terhadap masyarakat bahwa Daftar Pemilih Sementara telah dipampang di papan pengumuman pada lokasi yang telah ditentukan sehingga masyarakat tidak tau menahu tahapan pendaftaran wajib pilih mulai dilaksanakan.

2) Tidak adanya respon masyarakat terhadap proses pengumuman karena mereka menganggap telah terdaftar sebagai wajib pilih tanpa mengeceknya terlebih dahulu.

3) DPS yang dipampang hanya terpusat pada satu tempat saja sehingga sebagian masyarakat masih terlalu jauh untuk menjangkaunya.

Dari berbagai permasalahan tersebut diatas, diharapkan agar pihak penyelenggara :

1) Lebih intensif lagi dalam mensosialisasikan pengumuman kepada masyarakat terhadap proses pendaftaran pemilih

2) Agar Daftar Pemilih sementara ditempel dimasing-masing lingkungan sehingga bisa terjangkau oleh masyarakat.

Sedangkan bagi masyarakat yang diharapkan dalam proses ini adalah keterlibatannya langsung mulai dari awal hingga ditetapkannya pemilih sebagai DPT. Sehingga dengan demikian masyarakat akan tau persis mengenai prosedur yang ada dalam setiap tahapan. Kenyataan seperti ini kadang dianggap sepele oleh kebanyakan masyarakat tetapi justru hal inilah yang menjadi gambaran atau tolak ukur terhadap pola pikir masyarakat dalam mengambil bagian pada proses demokrasi.

Setelah proses tersebut diatas, selanjutnya pemilih perlu memastikan apakah dirinya benar-benar telah terdaftar sebagai wajib pilih dalam daftar pemilih sementara yang kemudian nantinya akan ditetapkan sebagai daftar pemilih tetap.

Rendahnya partisipasi masyarakat dalam hal memastikan dirinya terdaftar 
atau tidak dalam daftar pemilih berimplikasi pada sering terrjadinya kesalah pahaman antara masyarakat dengan Panitia Pemungutan Suara atau pihak penyelenggara Pemilu padahal sistim pendataan pemilih bersifat pasif artinya bahwa PPS hanya mengumumkan DPS yang diperoleh dari KPU kabupaten dan selanjutnya meminta respon masyarakat terhadap nama-nama yang diumumkan tersebut. Hal ini berarti bahwa partisipasi masyarakat dalam tahapan ini sangat diharapkan. Selanjutnya jika wajib pilih tidak terdaftar maka diharapkan agar segera menghubungi Panitia Pemungutan Suara (PPS) untuk dimasukkan dalam daftar pemilih tambahan yang nantinya akan dijadikan sebagai Daftar Pemilih Tetap (DPT).

Tingginya presentase partisipasi masyarakat untuk menghubungi panitia penyelenggara bagi mereka yang tidak terdaftar disebabkan oleh beberapa faktor antara lain :

1) Sudah ditetapkannya Daftar Pemilih Tetap dan waktu pelaksanaan pemungutan suara sudah dekat sehingga informasi mengenai daftar wajib pilih bisa diperoleh dari berbagai sumber.

2) Adanya kepentingan-kepentingan kandidat melalui tim suksesnya untuk mengecek nama-nama yang dianggap simpatisannya.

3) Tahapan pendaftaran pemilih masih berlangsung dalam artian bahwa partisipasi masyarakat sendiri yang muncul untuk didaftarkan sebagai wajib pilih.

Olehnya itu untuk meminimalisir permasalahan tersebut diatas maka diharapkan agar masyarakat tau tentang jadwal pendaftaran pemilih yang rentang waktunya biasanya beberapa bulan sebelum pemungutan suara.Kepada para elit politik diharapkan agar pengawasan pendaftaran pemilih dilakukan bersamaan dengan pengumuman Daftar Pemilih Sementara oleh PPS bukan nanti setelah ditetapkannya Daftar Pemilih Tetap sehingga tidak bisa lagi untuk didaftarkan.

\section{b. Pelaksanaan Kampanye}

Kampanye adalah salah satu tahapan dalam penyelenggaraan Pemilu yang dilakukan oleh pasangan calon Bupati / Wakil Bupati.Pada tahap ini, pasangan calon melakukan kampanye sesuai dengan jadwal yang telah ditetapkan oleh pihak penyelenggara pemilu. Dalam setiap kampanye, pasangan calon akan memaparkan visi dan misinya serta program kerja yang akan dilaksanakan bila nantinya mereka akan terpilih sebagai Bupati / Wakil Bupati. Hal ini dimaksudkan agar masyarakat dapat mengetahui apa saja yang menjadi program utama dari para calon tersebut sehingga ada suatu nilai perbandingan antara calon yang satu dengan yang lainnya.

Dalam Keputusan KPU Provinsi Sulawesi Tenggara Nomor 3 Tahun 2008 tentang Pedoman Teknis Kampanye Pemilihan Umum Bupati dan Wakil Bupati Buton disebutkan bahwa kampanye adalah suatu kegiatan yang dilakukan oleh pasangan calon dan/atau tim kampanye/juru kampanye untuk meyakinkan pemilih dalam rangka mendapatkan dukungan sebesar-besarnya, dengan menawarkan visi, misi dan program pasangan calon secara lisan atau tertulis dalam bentuk dan jadwal waktu yang telah ditetapkan.

\section{c. Pemungutan Suara}

Pemungutan suara merupakan puncak pelaksanaan pemilu, dimana seluruh masyarakat Kelurahan Jaya Bakti Kecamatan Sampolawa Kabupaten Buton yang terdaftar dalam Daftar Pemilih Tetap diharapkan ikut berpartisipasi dalam 
pemilihan kepala daerah tersebut agar seluruh masyarakat menentukan secara berama-sama siapa figur yang akan menjadi pemimpin di daerahnya lima tahun kedepan. Pemungutan suara dilakukan secara serentak di Kecamatan Sampolawa yang terdiri dari 12 Desa.Keterangan yang diberikan oleh Ketua KPUD Kabupaten Buton menggambarkan bahwa secara umum pelaksanaan pemungutan suara berlangsung secara tertib dan aman.Tidak ada hambatan yang berarti dalam melaksanakan pemungutan sura. Hal ini karena adanya koordinasi yang baik antara semua pihak yang terlibat baik KPUD, beserta PPK, PPS, dan KPPS dan juga senantiasa diawasi oleh panwaslu serta peran serta atau partisipasi masyarakat sendiri dalam menjaga keamanan dan ketertiban di lingkungannya masingmasing.

Sebelum hari pemungutan suara, KPPS memberikan kartu panggilan kepada para wajib pilih.Pemberian kartu panggilan tersebut tentunya berdasarkan Daftar Pemilih Tetap yang telah disahkan oleh Panitia Pemungutan Suara yang sudah dibagi berdasarkan jumlah TPS yang ada.Dalam pelaksanaan pemungutan suara, yang berhak memberikan suaranya yaitu mereka yang telah mempunyai kartu panggilan.

Masih adanya wajib pilih yang tidak diberikan kartu panggilan disebabkan oleh yang bersangkutan tidak terdaftar dalam Daftar Pemilih Tetap sehingga mereka tidak dibenarkan untuk melakukan pemungutan suara.Sesuai dengan Undang-Undang Nomor 10 Tahun 2008 tentang Pemilihan Umum Anggota Dewan Perwakilan rakyat, Dewan Perwakilan Daerah dan Dewan Perwakilan Rakyat Daerah Pasal 149 ayat 1 yaitu Pemilih yang berhak mengikuti pemungutan suara di TPS meliputi :

1) Pemilih yang terdaftar pada daftar pemilih tetap pada TPS yang bersangkutan, dan
2) Pemilih yang terdaftar pada daftar pemilih tambahan.

Oleh karena itu maka bagi yang tidak terdaftar dalam daftar pemilih tetap tidak diberikan kartu panggilan dan secara otomatis tidak dibolehkan untuk memilih.Dengan demikian maka semua wajib pilih harus memastikan namanya dalam DPT untuk kemudian dapat diberikan kartu panggilan.

Selanjutnya menjelang pemungutan suara kemungkinan adanya intervensi dari pihak lain kepada pemilih untuk memilih para calon.

Intevensi yang dimaksud pada kata ini bukanlah mempengaruhi seseorang seperti halnya berkampanye atau mengkampanyekan calon ke orang-orang untuk dipilih atau berupa pemberian uang berupa transportasi untuk datang melakukan kampanye tetapi intervensi yang dimaksud adalah berupa pemaksaan kehendak kepada wajib pilih untuk memilih seseorang calon atau lebih bersifat kekerasan / anarkis. Dari semua wajib pilih yang telah diberikan kartu panggilan tentunya tidak semua akan hadir untuk melaksanakan pemilihan.

Dari gambaran tersebut, dapat dilihat bahwa tingkat partisipasi masyarakat dalam pemungutan suara masih sangat rendah. Rendahnya partisipasi tersebut dapat disebabkan oleh beberapa faktor antara lain :

1) Wajib pilih tidak berada di tempat pada saat pemungutan suara

2) Sebagian masyarakat tidak melakukan pemilihan (golput)

3) Sebagian pemilih sudah lanjut usia sehingga untuk menuju ketempat pemungutan suara sudah tidak memungkinkan.

4) Pembagian wajib pilih yang teracak atau tidak berdasarkan pada kedekatan dengan lokasi tempat pemilihan.

Dari berbagai permasalahan 
tersebut diatas, diharapkan agar pihak penyelenggara dapat menempatkan tempat pemungutan suara yang mudah terjangkau bagi masyarakat bukan saja dari kalangan muda tetapi kalangan tua sekalipun dapat menjangkau lokasi tempat pemungutan suara sehingga permasalahan tersebut dapat diminimalisir.

\section{Penutup}

\section{Kesimpulan}

Berdasarkan pembahasan diatas maka kesimpulan yang dapat ditarik adalah sebagai berikut :

1) Masih rendahnya partisipasi masyarakat terhadap pelaksanaan pendaftaran pemilih pada Pemilukada di Kelurahan Jaya Bakti Kecamatan Sampolawa Kabupaten Buton di sebabkan oleh disamping tidak tahunya masyarakat tentang tahapan pendaftaran wajib pilih juga karena lokasi tempat dipampangnya pengumuman Daftar Pemilih hanya terdapat pada satu titik saja.

2) Dalam pelaksanaan kampanye, partisipasi masyarakat hanya bersifat hiburan dan tidak melihat pada visi dan misi yang di paparkan oleh para calon Bupati/Wakil Bupati.

3) Rendahnya partisipasi masyarakat pada pemungutan suara disebabkan oleh ketidakberadaan wajib pilih pada hari pemungutan suara, mereka tidak mau melaksanakan hak wajib pilihnya (golput) dan jauhnya tempat pemungutan suara dengan tempat tinggalnya.

\section{Saran}

Adapun saran-saran yang yang perlu diperhatikan adalah sebagai berikut :

1) Dengan masih rendahnya partisipasi masyarakat dalam semua tahapan penyelenggaraan Pemilukada di Kelurahan Jaya Bakti Kecamatan
Sampolawa Kabupaten Buton maka diharapkan agar pada pemilu-pemilu selanjutnya penyelenggara lebih mensosialisasikan semua tahapan secara berjenjang.

2) Diharapkan agar pengumuman daftar wajib pilih sementara ditempel pada masing-masing lingkungan sehingga mudah dilihat oleh semua masyarakat

3) Dalam penempatan wajib pilih pada masing-masing TPS agar mempertimbangkan kedekatan dengan lokasi tempat tinggalnya. 


\section{E. DAFTAR PUSTAKA}

Ach. Wazir Ws.,et al., ed. 1999. Panduan Penguatan Menejemen Lembaga Swadaya Masyarakat. Jakarta: Sekretariat Bina Desa dengan dukungan AusAID melalui Indonesia HIV/AIDS and STD Prevention and Care Project.

Arikunto, Suharsimi, 2002, Prosedur Penelitian suatu Pendekatan Praktek,Jakarta :Rineka Cipta. 2006, Prosedur Penelitian suatu Pendekatan Praktek,Jakarta :Rineka Cipta.

Isbandi Rukminto Adi. 2007. Perencanaan Partisipatoris Berbasis Aset Komunitas: dari Pemikiran Menuju Penerapan.Depok.FISIP UI Press.

Koentjaraningrat.1982.Beberapa Pokok Antropologi Sosial.Jakarta : Dian Rakyat.

Mikkelsen, Britha. (1999). Metode Penelitian Partisipatoris dan Upaya-upaya Pemberdayaan: sebuah buku pegangan bagi para praktisi lapangan. Jakarta: Yayasan Obor Indonesia

Miles, Mathew. B dan Huberman, Michael A, 1992, Analisa Data Kualitatif, Terjemahan,Jakarta:UI Press

Nazir, Muhammad, 1999, Metodologi Penelitian, Ghalia Indonesia, kerjasama Yayasan Bina Dharma dengan Universitas Kristen Satya Wacana, salatiga.

Sugiono. 1998.Metode Penelitian Administrasi, Alfabeta..Bandung :CV.Arum Bangkit.
Sumampouw, Monique. (2004). "Perencanaan Darat-Laut yang Terintegrasi dengan Menggunakan Informasi Spasial yang Partisipatif." Jacub Rais, et al. Menata Ruang Laut Terpadu. Jakarta: Pradnya Paramita.

Sevilla, et.al.1993.Pengantar Metode Penelitian.Jakarta :P.T. Prasshalindo.

Undang-Undang No. 32 Tahun 2004 Tentang Pemerintahan Daerah.

Undang-Undang No. 10 Tahun 2008 Tentang Pemilihan Umum Anggota Dewan Perwakilan Rakyat, Dewan Perwakilan Daerah dan Dewan Perwakilan Rakyat Daerah.

Peraturan KPU No. 63 Tahun 2009 tentang Pedoman Penyusunan Tata Kerja KPU Provinsi, KPU Kabupaten/Kota, PPK, PPS dan KPPS dalam pemilihan umum kepala daerah dan wakil kepala daerah. 